IN THE KINGDOM OF SOLOVIA:

THE RISE OF GROWTH ECONOMICS AT MIT, 1956-1970*

BY MAURO BOIANOVSKY

AND

KEVIN D. HOOVER

CHOPE Working Paper No. 2013-04

June 2013

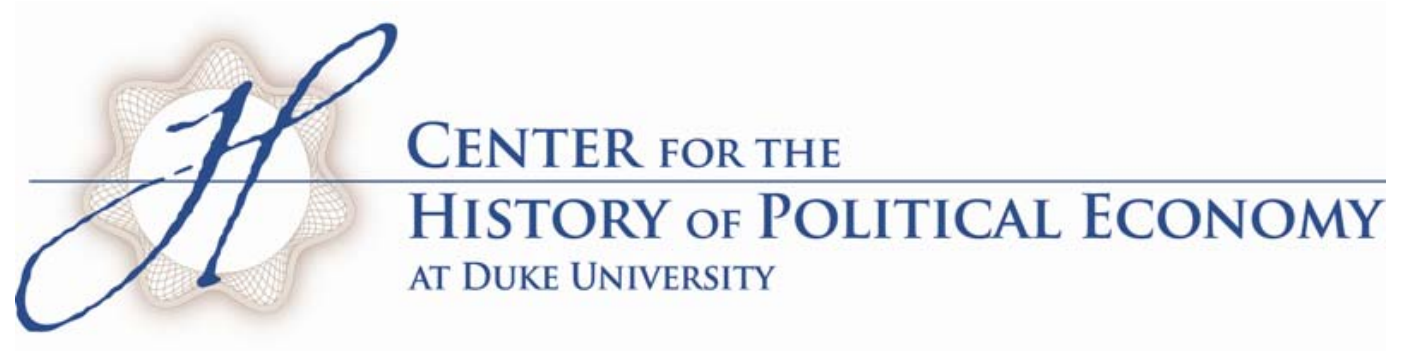




\title{
In the Kingdom of Solovia: The Rise of Growth Economics at MIT, 1956-1970*
}

\author{
Mauro Boianovsky \\ Department of Economics \\ Universidade de Brasilia \\ Brasilia DF 70910-900 \\ Brazil \\ Tel. +61-3107-6583 \\ E-mail mboianovsky@gmail.com
}

\author{
Kevin D. Hoover \\ Department of Economics \\ Department of Philosophy \\ Duke University \\ Box 90097 \\ Durham, NC 27278 \\ U.S.A. \\ Tel.+919-660-1876 \\ E-mail kd.hoover@duke.edu
}

24 June 2013

\begin{abstract}
*We thank G.C. Harcourt, Eytan Sheshinski, Edwin Burmeister, Peter Diamond, William Nordhaus and participants at the conference on "MIT and the Transformation of American Economics” (Duke University, 26-28 April 2013) for helpful comments on an earlier draft, and Matthew Panhans for efficient research assistance. Mauro Boianovsky gratefully acknowledges a research grant from CNPq (Brazilian Research Council).
\end{abstract}




\begin{abstract}
From its flow tide, fueled by the Cold War, to its ebbing with the anti-growth movement and the economic crises of the early 1970s, the "growthmen" of MIT stood at the center of the dominant field in macroeconomics. The history of MIT growth economics is traced from Solow's seminal neoclassical growth model of 1956 through the stabilization of growth theory in the first graduate textbooks.
\end{abstract}

JEL Codes: B2, B22, O4, O11, E12, E13

Keywords: growth theory, development economics, MIT, Robert Solow, endogenous growth models, technical progress 


\section{In the Kingdom of Solovia: The Rise of Growth Economics at MIT, 1956-1970}

\section{Growthmanship}

The Massachusetts Institute of Technology (MIT) in the early 1960s was the native land of the “growthmen.” In 1948, its leading light, Paul Samuelson, had published a path-breaking undergraduate textbook, Economics: An Introductory Analysis. The book was striking in part because it gave pride of place to the analysis of national income and outlined the vision of the “mixed economy” in which Keynesian demand management would secure full employment and the price system operating under the usual neoclassical analysis would govern allocation (Pearce and Hoover 1995). (By the third edition this stance gained a name: "the neoclassical synthesis" (Samuelson 1955, p. vi).) The focus was essentially on the short run - avoiding a replay of the Great Depression and combatting the anticipated postwar slump loomed large in Samuelson’s vision. He paid no attention to economic growth per se. In the sixth edition of Economics, Samuelson (1964, ch. 35) added a "new chapter on the theory of growth" (p. vi). Samuelson had become a growthman.

Richard Nixon coined "growthmanship” in the bitterly contested presidential election of 1960. No less a Cold Warrior than Nixon, Kennedy had previously harped on the (later discredited) “missile gap” with the Soviet Union. And putting Vice President Nixon on the defensive with regard to the economic stewardship of the Eisenhower administration, he saw an economic gap as well: Western Europe and, especially, the Soviet Union appeared to have grown economically far faster than United States (Solow 1964, p. 101; Samuelson 1961, p. 802). Nixon used “growthman” to abuse Kennedy’s single-mindedness in allowing growth to dominate the political debate (Tobin 1964; Arndt 1978, chapter 5; Collins 2000, chapter 1). 
Growthmanship was originally informed by policy concerns, rather than formal economic theory (Collins 2000, ch. 1). Walt Rostow, a colleague of Samuelson’s at MIT, became a national-security adviser in the Kennedy administration. But Rostow was an economic historian, not a theorist. His book, The Stages of Growth: A Non-Communist Manifesto (1960) influenced the formulation of American security policy (Lodewijks 1991). Yet, as its subtitle suggests, the practical concern of winning the Cold War dominated formal economic analysis. Samuelson himself acknowledged the Soviet challenge, and criticized the belief - presumably based on the notion of diminishing returns assumption - that the Soviet Union's rate of growth would have to slow down as its economy approached American levels of economic development as "wishful thinking” and "rightwing determinism” (Samuelson 1964, p. 723). It was characteristic, however, of Samuelson and MIT at this period to emphasize the utility of economic analysis for policy. Indeed, what perhaps most distinguished Economics from earlier textbooks was the way in which, even an elementary exposition, was informed by formal analysis. In the sixth edition, Samuelson drew on the work on growth theory of his younger colleague Robert Solow (1956) an indication that growthmanship was taking an analytical turn. Solow, who also worked in the Kennedy administration, had happily adopted Nixon’s term of abuse: he was a "growthman” and “growthmanship has become respectable” (Solow [1962]1964, pp. 101-103).

The MIT economists were thus growthmen in two senses: in seeing growth as an absolutely central policy imperative and in seeing the theory of growth as a focus for economic research. The first fed the second. Evsey Domar, a growth economist and expert on the economy of the Soviet Union, captured the policy imperative: economic growth was the "fashion of the day" because, when "an aggressive part of the world is strongly and quite successfully committed to rapid growth, the other can disregard this objective only if it is tired of 
its own existence as a society” (Domar 1957, pp. 14-15). Growth theory itself was a substantive field in economics, at least since the late 1940s. What the MIT growthmen added was a distinctive style of analysis that made it easier to address the dominant policy concerns in tractable formal models. Solow's (1956) model was the perfect exemplar of the MIT style. It provided the central framework for the subsequent developments in growth theory and secured MIT as the center of the universe in the golden age of growth theory in the 1960s. To Eytan Sheshinski (1990, p. 41), an MIT graduate student from 1963 to 1966, the “Solovian equipment” was a "natural monopoly with a non-duplicable resource" operating in high gear throughout the decade. Both the centrality of Solow's growth model and the policy imperative are captured nicely in the opening of Edmund Phelps’s “A Fable for Growthmen”:

Once upon a time the Kingdom of Solovia was gripped by a great debate. "This is a growing economy but it can grow faster," many argued. "Sustainable growth is best," came the reply,"and that can come only from natural forces."

A few called the debate growthmanship. But most thought it would be healthy if it led to a better understanding of Solovian growth. So the King appointed a task force to learn the facts of Solovian economic life. [Phelps 1961, p. 638]

\section{Founding the Kingdom}

The development of growth theory in the 1950s has been documented by a variety of historians (e.g., Boianovsky and Hoover 2009a, Halsmayer and Hoover 2013, and Halsmayer this volume). Solow (1956) and the Australian economist Trevor Swan (1956) each developed independently what is essentially the same model, now often referred to as the neoclassical growth model (Dimand and Spencer 2009). The single-sector neoclassical growth model appears to be an elegant theoretical exercise in which aggregate economic growth is characterized by a single first-order differential equation. But Solow’s version arose ultimately from empirical and 
pedagogical concerns. ${ }^{1}$ Solow, who was the student of Wassily Leontief at Harvard, had worked on the empirical implementation of Leontief's input-output analysis, constructing large multisectoral tables for the United States. In the early 1950s, Solow, who had taken up a post at MIT, worked with Samuelson to analyze the theory of dynamic input-output analysis. This work was tied closely to work on activity analysis and linear von Neumann growth models, some of which informed Dorfman, Samuelson, and Solow's Linear Programing and Economic Analysis (1958). While much of this work was theoretical, it was empirically motivated and supported in part under defense contracts.

Solow's (1956) model grew out this work. He regarded its core to be a “collapsed production function” that helped him to characterize and explore the causal dynamics of the aggregate economy in a transparent way for his MIT engineering students. Solow regarded the model as a tool - a drastic simplification of the complexities that he had explored with Leontief and Samuelson, but not a denial of them, and not a turning away from empirical motivations. He used the model to teach craftsmanship to provide a basis for "reconnaissance exercises" to understand what factors really matter for the way in which the economy behaves. An early exercise - not in fact by Solow himself, but by Swan (1956), his co-discoverer of the neoclassical growth model - was a surprise: the rate of growth in the neoclassical growth model is independent of the rate of investment (or savings).

Solow’s model arrived at a propitious moment for growth economics. He offered three reasons to account for the turn to growth economics after the mid-1950s: (i) the political attention given to the problem of the economic development of preindustrial areas; (ii) the intellectual pursuit of extending Keynesian macroeconomics into the long-run, initiated by

\footnotetext{
${ }^{1}$ The remainder of this section draws on Halsmayer (this volume).
} 
Harrod and Domar; and (iii) the feeling that "short-run macroeconomic theory is pretty well in hand ... all that is left is the trivial job of filling in the empty boxes” (Solow [1962] 1964, pp. 101-103). The neoclassical model proved to be the principal tool in the analytical turn to growth and the workhorse of growth research, not only in MIT's Economics Department but around the world.

\section{Development Economics and the Cold War}

At the time of the publication of Solow's neoclassical growth model, MIT was already deeply engaged with growth as a front in the Cold War. In addition to the direct worry about the United States being eclipsed by the East Bloc - 1956 was also the year that Nikita Khrushchev declared to the West, "We will bury you!" (cited by Samuelson 1964, p. 723) - the First World of the Western democracies competed with the Second World of the communist states for the allegiance of the Third World of newly independent and developing countries. A central question was, which economic system would lift the Third World out of poverty? Understanding growth was the key to development economics. Rostow had joined MIT as part of the newly created Center for International Studies (CENIS) in 1951. He was joined two years later by the economist Paul Rosenstein-Rodan. The work at CENIS was not mathematical. Rostow and Rosenstein-Rodan understood the growth process to be complex and viewed developing countries as facing special hurdles that impeded any spontaneous convergence to Western standards of living. In an influential article, Rostow introduced the idea of a "Take-Off Into Self-Sustained Growth” (1956; see also 1960). In a similar vein, Rosenstein-Rodan (1943) had already argued that poor economies with large agricultural sectors could be moved to a path of 
sustained growth only through a deliberate massive investment in industrial capital - a "Big Push.”

The economists at CENIS were skeptical of the value of formal economic models as guides to development. Rosenstein-Rodan’s (1961) essay (originally a CENIS working paper in 1957), did not cite Solow or any other growth theorist directly but nonetheless, offered a sustained criticism of neoclassical growth theory. Growth models built on production functions that were homogeneous of degree one in factors of production were deemed "completely unrealistic,” since they implied “no economies of scale or of agglomeration, no entrepreneurship, no phenomenon of minimum quantum or threshold” (Rosenstein-Rodan 1961, p. 60). Rosenstein-Rodan based his theory of the Big Push on the assumption of indivisibilities in the production functions - particularly in the form of social overhead capital - which generated increasing returns to scale and external economies. The rate of return in each industry, he believed, is influenced by demand from complementary ones, opening up the possibility of coordination failures in which the economy becomes trapped in a low-level equilibrium. The Big Push - a policy intervention that created a coordinated quantum of investment in different sectors - aimed at internalizing the external economies to establish balanced growth. (Also see the work of his MIT colleague Charles Kindleberger (1965, chapter 9).)

International trade, Rosenstein-Rodan (1961, pp. 63-65), believed, could reduce, but not eliminate, the size of the required quantum of investment. Here he directly challenged the relevance of Samuelson’s (1948b) well-known factor-price equalization theorem: Historical experience did not support its implication that wages and rates of return would converge among different countries. Nonetheless, he quoted approvingly Samuelson’s (1948b) own suggestion that different production functions and technology in each country caused the observed 
divergences. The differences in technology were not, in Samuelson's view, a matter of the relative scarcity of knowledge, which he considered a “crypto-explanation”: knowledge "is not an input such that the more you use of it, the less there is left” (Samuelson 1948b, p. 181).

Similarly, Rosenstein-Rodan (1961) challenged another prediction of trade theory: abundant manpower should result in low wages, which should attract capital from abroad, driving up wages and income. However, "lower wages in underdeveloped countries did not attract enough capital to reduce the inequality in factor rewards nor did international trade fully achieve this effect” (p. 66). Orthodox theory had neglected external economies, in the sense that the deficiency of social overhead capital caused "diseconomies on capital account which more than outweighed any economies on wage account” (p. 66). ${ }^{2}$

The difference between the economists of the Economics Department and those of CENIS were not so much about the aims of policy or even the underlying causes of underdevelopment per se, but rather about the appropriate methodology for addressing the messy, complex problem of underdevelopment and the relevance of highly simplified theoretical models - differences brought into clear relief in September 1960 at a conference of the International Economic Association held at Konstanz in West Germany to examine Rostow’s (1956, 1960) economics of take-off into sustained growth (Rostow 1963). Solow’s final statement and assessment in the final session of the conference (Rostow 1963, pp. 468-74) illustrates the difficult dialogue between economic historians and growth theorists. Solow taxed Rostow with failing to establish an "orderly relation between economic theory and economic history," which should start with a clear distinction between initial conditions, laws of behavior

\footnotetext{
2 Thirty years later, Lucas (1988, pp. 15-17) would mount a similar criticism of the neoclassical theory of trade and growth.
} 
and parameters. Rostow (1963, pp. xiii-xxvi; see also Rostow 1984, pp. 235-37) accepted the challenge: in his after-conference "introduction and epilogue," he tried to give the concept of Take-off some added precision. He maintained, nonetheless, that economic theory was a "world of problems of simplicity", unable to function in the "world of organized complexity" of economic growth (Rostow 1963, p. xxiv).

Solow, of course, dissented - but not because he challenged the notion of Take-off. He did believe that surrendering to the complex details of the growth process was to give up too soon on understanding the causal essence of the problem. He had already suggested a way in which the neoclassical growth model might generate multiple equilibria and explain a poverty trap (Solow 1956, pp. 90-91). In the basic model, the steady-state is achieved at a unique capital-labor ratio $(r)$ where the need for capital to outfit a growing workforce at that ratio (capital widening) exactly equals savings (or investment). ${ }^{3}$ In an extension of the basic model, Solow considers what happens if the rate the rate of population growth depends on per capita income, which is itself a function of the capital-labor ratio. Population decreases for very low levels of income; it begins to increase for higher levels of income; and declines for still higher levels. Because of the variable rate of population growth, the needs for capital widening will match the available savings (or investment) at two different capital-labor ratios. Solow shows that the larger of these $\left(r_{2}\right)$ is unstable, in the sense that, if the initial ratio is less that $r_{2}$, the economy will tend to return to the lower steady-state at $r_{1}$ and, if it is greater than $r_{2}$, the economy will move to a non-steady-state growth path in which the capital-labor ratio increases (capital deepening). But the lower ratio corresponds to a low per capita income. The stability of

\footnotetext{
${ }^{3}$ Solow (1956) indicated the capital-labor ratio by $r$, while most subsequent expositions of the neoclassical growth model use $k$.
} 
this low steady state marks it out as a poverty trap. If on the other hand, a Big Push (to use Rosenstein-Rodan's but not Solow's term) could drive the economy above $r_{2}$, then the instability would carry the economy toward rising capital-labor ratios with rising per capita incomes - a take-off to a path of self-sustained growth. Solow remarks:

The interesting thing about this case is that it shows how, in the total absence of indivisibilities or of increasing returns, a situation may still arise in which small-scale capital accumulation only leads back to stagnation but a major burst of investment can lift the system into a self-generating expansion of income and capital per head. The reader can work out still other possibilities. [Solow 1956, p. 91; emphasis added]

Despite being published in 1956, Solow's version of the Big Push reads as if he was reacting to Rosenstein-Rodan’s 1957 CENIS essay (published in 1961). In all likelihood, Solow was familiar with Rosenstein-Rodan's earlier essay (1943) and the main ideas of the essay were already current at MIT. ${ }^{4}$

Solow’s (1956) account of poverty traps illustrates a methodological strategy: keep the models simple, yet adapt them to the demands of the real world. Solow's remark about "other possibilities” illustrates that he regarded his analysis as a "reconnaissance exercise” and a demonstration of the capacities of his model qua tool of analysis. He did not see his models as competing with the work of the historians or development economists, but as clarifying the causal mechanisms that lay behind the facts that they documented. Those facts included the differences in income levels and growth rates between developed and underdeveloped countries. Confirming Kaldor’s (1961, pp. 178-79) sixth “stylised fact” of economic growth, Samuelson (1964, p. 757) observed that "in contrast to the narrowing of income differentials within the

\footnotetext{
${ }^{4}$ On the occasion of the conferring of the degree of Doctor of Humane Letters to Rosenstein-Rodan in 1982, Solow recalled that it was not easy for the relatively small MIT department of economics in the 1950s to absorb CENIS, with its large number of senior scholars in one specialized field. Rosenstein-Rodan was a key figure in the process, because he "saw himself and wanted others to see him as someone in the main stream of economics, and not as the practitioner of some rather different art ... to be measured against different standards” (Solow Papers, Box 59).
} 
advanced nations, the divergence between advanced and underdeveloped countries is probably now widening rather than narrowing.”

What lay behind the differences between developed and developing countries? To the extent that development economists employed a formal model of growth, it was the HarrodDomar model, which was interpreted as a neoclassical growth model with a production function with technologically fixed proportions (fixed coefficients) between capital and labor (Harrod 1939, 1948; Domar 1946). ${ }^{5}$ ) The Harrod-Domar model appeared to suit the problems of development, since it readily explained situations in which labor was in excess supply and capital was a binding constraint. It connected growth rates in both the short and long runs to increases in investment rates and opened up the possibility of a self-sustaining growth path from the massive underutilization of a poverty trap to full employment at a high "natural rate" of growth (see e.g. Boianovsky 2010).

Some of the very features that recommend the Harrod-Domar model to development economists were the direct target of Solow’s (1956) paper. In particular, the same mechanism that offered the possibility of self-sustained growth for an impoverished country seemed to suggest the fragility of steady-state growth paths, predicting that developed economies would be susceptible to self-reinforcing collapse. Solow attributed this property to the assumption of a fixed-proportions production function. In reality, he believed, the mix of factors of production responded to price signals, and a flexible-proportions production function (such as the CobbDouglas or constant-elasticity of substitution (CES) production functions) would not suffer from the instability problem (see Halsmayer and Hoover 2013). Domar, who had been recruited to

\footnotetext{
${ }^{5}$ Halsmayer and Hoover (2013) show that the interpretation of Harrod's model either as a growth model or as embodying a fixed-proportions production function (or, indeed, any production function) is untrue to Harrod's purpose or presentation. It remains true, however, that Harrod was widely interpreted in this way and that his analysis was typically assimilated to Domar's.
} 
MIT in 1958, recanted his growth models of the 1940s and endorsed Solow's approach, with its “less rigid production function” (Domar 1957, pp. 7-8).

By the mid-1960s, Samuelson (1964, p. 760) argued that development economists had no unified theory differing from the dominant growth model, but that they did add to it some “special features.” The Solow model predicted that, given some parameters (savings and fertility rates), economies move to their steady states. Because of diminishing returns, countries with lower capital-labor ratios would have a high rate of return to capital. Hence, controlling for savings rates, poorer countries would tend to go faster and converge. But clearly, poorer countries were not converging very rapidly, if at all, toward developing countries per capita income. Samuelson (1964, p. 752) argued that, for the "poor countries there must be added the important additional concepts of 'external economies,' 'social overhead capital,' and 'increasing returns'.” Neoclassical diminishing returns and constant returns to scale should be replaced in “dynamic economic development," by "increasing returns," which "can make it possible for the dramatic spurts and acceleration to occur in economic development” (Samuelson 1964, pp. 76162). ${ }^{6}$ Samuelson associated those discontinuities in the development process with Rostow's Take-off and, especially, with Rosenstein-Rodan’s Big Push - a view that focused on multiple equilibria rather than on convergence to steady states.

Thus, there was substantial agreement with CENIS on the goals of policy. But in contrast to Rostow and Rosenstein-Rodan's skepticism about the theory, Solow advocated the flexible adaptation of simple, formal models to different aspects of the development problem. He

\footnotetext{
${ }^{6}$ Samuelson, however, did not formalize the argument. After the matter was tackled by "new growth theory", he recalled that "the problem with increasing scale returns is that after you have said the first things about it, it is deucedly hard to find interesting second and third themes to develop. Most pretty modern mathematics lacks elegant applications to the combinatorial swamp that nonconexity irreducibly entails. My conscience was long bothered by our guild's neglect of a subject on the ground that it is so hard to tackle" (Samuelson 2001, p. 499).
} 
recognized that the actual substantive application of economic analysis to development would have to move beyond the reconnaissance stage, and that was difficult work. As a consequence formal growth economics and economic development would fracture into distinct fields.

On the one hand, the fracture was a typical division of labor: the development of methods belonged to growth economics; the applications to policy problems belonged to development. On the other hand, Solow's reconnaissance exercises had already begun to show that the special assumptions needed to fit the neoclassical growth model to developed and developing economies would be different, so that growth economics and development economics were also distinguished by their domain of application.

Seen this way, the debate in the late 1950s and early 1960s over the realism and relevance of the neoclassical growth model, gave way to the systematic adaptation of it to the needs of development economics. At the Konstanz conference, Solow complained that no mention had been made of Arthur Lewis’s (1954) concept of dual economies in which underemployment in the traditional low-productivity sectors results in an infinitely elastic supply of labor at an exogenous real wage rate (Rostow 1963, p. 472). By the end of our period, economists in both the Economics Department and CENIS were following through on Solow's preferred strategy: Stephen Marglin (1967) and Sukhamoy Chakrvarty (1969) both at CENIS and Avinash Dixit (1968a, b; 1973) in the department deployed optimal control theory to investigate the choice of techniques and growth paths in economies with a surplus of labor (Burmeister-Dobell 1970, pp. 408-09). Samuelson’s preface to Chakravarty (1969) illustrates the mutually beneficial trade between growth and development economics at MIT. 


\section{Setting the Agenda}

Formal modeling of economic growth at MIT was never an abstract enterprise, but was always motivated by underlying policy concerns, a respect for empirical results, and a goal of providing illuminating and relevant tools. But the models were artifacts in their own right, subject to their own constraints and imperatives (see Halsmayer, this volume). Much of the 1960s was devoted to the formal elaboration of the models, but based on an agenda set in the second half of the 1950s.

In the short, final section of his article on the "policy implications" of his growth model, Solow (1956, p. 93) cited Samuelson in support of the view that the rate of growth should be one of the targets of macroeconomic policy. Samuelson ([1956] 1969, p. 73) claimed that "with proper fiscal and monetary policies, our economy can have full employment and whatever rate of capital formation and growth it wants” - a position that he viewed as an element of the “neoclassical synthesis” (Samuelson 1961, p. 807). One of the faults of the Harrod-Domar model, in Samuelson's view, was that, by regarding technology as fixed, it suggested that economic policy would be helpless to deepen capital and raise per capita income, once surplus labor had been absorbed, and that, once fully employed, society must "accept the growth rate that fate meets out to it” (Samuelson (1961, p. 809, n. 1; see also 1964, p. 788). Samuelson (1961, p. 809, n. 1) argues that it is "misleading to think [as implied by the Harrod-Domar model] that growth is fatalistically determined by some simple formula involving the saving and capitaloutput ratios.” That formula allows a warranted rate of growth that exceeds the natural rate of growth of population and, therefore, cannot last long:

If deepening of capital were impossible, so that the capital-output ratio could never be increased, fiscal policy would have to be set fatalistically at so expansionary a level as to bring down the percentage of income saved to the level set by the rate of population 
growth and the capital-output ratio. Society would have to accept passively this fate-given growth rate (plus what technical change will itself bring). (Samuelson 1961, p. 809, n. 1)

Here Samuelson appears to argue that it is the neoclassical growth model with its flexible capital-output ratio, rather than the Harrod-Domar model, that offers hope for growth-promoting macroeconomic policy. He viewed the Kennedy administration’s investment tax credit of 1962 as an application of that conception (Samuelson 1964, p. 787).

In retrospect, Samuelson appears to have muddle up different issues. A flexibleproportions production function does permit capital deepening not available in the HarrodDomar model. But the neoclassical model, unlike the Harrod-Domar model, builds in the convergence of the warranted rate of growth, given by savings and production technology, to a steady-state natural rate of growth, given by population and the rate of technical progress. At this point, Samuelson's optimism about growth policy seems not to have fully taken on board two challenges exposed by the neoclassical growth model itself.

The first was the "stunning result” (Stiglitz 1990, p. 52) that the rate of growth in the neoclassical growth model is independent of the rate of savings. In his own paper, the codiscoverer of the neoclassical growth model, Swan (1956, pp. 337-38), had already noted what was only in implicit in Solow's analysis: increases in investment (or savings) rates can boost the rate of growth initially and deepen capital, but diminishing returns to factors of production imply that the increased rate of growth ultimately plays itself out when the extra output is just sufficient to cover the needs of capital widening. ${ }^{7}$ At that point, the economy is returned to the same steady-state growth rate, though at a higher capital-output ratio. A few years later, James Meade

\footnotetext{
${ }^{7}$ Swan visited MIT in 1958.
} 
further elaborated what was regarded as a "most paradoxical conclusion” (Meade 1962, pp. 4245, 110-13). Still, the point took a while to sink in.

Swan (pp. 338-39) remarked that the “anti-accumulation” implications of the neoclassical growth model could be mitigated if the rate of technological progress depended on capital accumulation. Investment could generate external economies, which would render the social yield of capital higher than its private value and bring about increasing returns to scale. Moreover, the rate of population growth might not be independent of the rate of accumulation, which was the "distinctively classical answer.” Solow (1956) had already made a related point in his discussion of the poverty trap (see section III above).

The second challenge to Samuelson's optimism about growth-promoting policy was framed by Solow's brief, but influential, foray into empirical research. Using the constantreturns-to-scale production function that formed the heart of the neoclassical growth model, Solow (1957) developed an accounting framework that attributed definite fractions of U.S. economic growth between 1909 and 1949 to the different factors of production. He treated the unattributed share of growth to technical progress. The result was deeply surprising to those who saw growth as driven principally by capital accumulation: the growth in technical progress accounted for the lion's share of overall growth in U.S. gross national product. The challenge to the neoclassical growth model was simply that technical progress had hitherto been taken to be an exogenous factor, and an exogenous factor does not amount to a substantive explanation. The lack of explanatory force was highlighted by the common practice of referring to technical progress measured this way as a “residual."8

\footnotetext{
8 The practice of referring to the component of the measured growth rate of output per capita unaccounted for by capital deepening as the "residual” may be due to Domar (1961, p. 709). Kindleberger (1965, p. 150) ascribed to
} 
Solow (1960) suggested a modification to the neoclassical growth model that he hoped would simultaneously address both challenges. In Solow's (1957) paper, technical progress is disembodied - that is, it adds to output merely through the passage of time, as if it did not have to be physically incorporated into the means of production. Solow (1960) sought to relax the assumption that "the pace of investment has no influence on the rate at which technique improves” (p. 90). He allowed the rate of technological knowledge progress in this disembodied manner, but modeled it as adding to productive capacity only to the degree that it was embodied in new capital goods. The productivity of any particular piece of capital would depend, therefore, on its vintage. Faster investment would raise the rate of growth in the economy by accelerating the incorporation of new knowledge into the capital stock, answering the first challenge. And the residual would be - at least partly - explained as an endogenous response to investment rates. Of course, the underlying rate of improvement in technical know-how itself remained unexplained.

Samuelson and Solow were both optimistic about the "new view" of investment (Phelps 1962). ${ }^{9}$ Based on his idea of vintage capital, Solow (1962) constructed econometric estimates of the rates of investment necessary to accelerate American economic growth in the following decade. His vintage-capital model and these estimates were used to provide the benchmark for the chapter on growth in the 1962 Economic Report of the President's Council of Economic Advisers, which Solow drafted in his capacity as a staff economist.

\footnotetext{
Rosenstein-Rodan the notion that the "residual growth" is the result of external economies of scale. Later, in the literature on real business cycle models, the "residual" becomes the "Solow residual" (see Hartley, Hoover, and Salyer 1997, 1998).

${ }^{9}$ Samuelson (1964, p. 737) suggested as much in his observation that "innovations can be introduced faster in a society which is performing net investment in addition to the gross investment ... the society which gets to try out more new things will run that much ahead of the one which does little or no saving”.
} 
Optimism that "new view" of investment would meet the two challenges exposed by the neoclassical growth model was soon dashed. Phelps (1962), who visited MIT in 1962-63, demonstrated that in a vintage-capital model a once-and-for-all change in the saving ratio cannot permanently alter the age distribution of capital. Thus, it can accelerate the rate of growth in the transition between steady states in the vintage model, which might make a substantial difference over a 10- or 20-year period, but the steady rate is still determined by the rates of growth of population and of the underlying (exogenous) technical knowledge (Solow [1962] 1964, p. 108; 1970, p. 55). Solow ([1968] 1969, pp. 94-97) concluded from cross-section and historical evidence that “fast-growing countries are high-investment countries”, despite the theoretical irrelevance of the investment ratio for the determination of long-run growth.

The two challenges were thus unmet. But they set a two-fold agenda for research into formal growth models in the Kingdom of Solovia in the 1960s. One focus would be optimal growth, which had three aspects: i) the optimal capital-labor ratio; ii) if it was susceptible to policy intervention - as it was not in the earlier neoclassical models, the optimal growth rate; and iii) the optimal rate of transition between steady states. The second (and not completely independent) focus was to explain or endogenize technical progress. This agenda was pursued by a number of MIT graduate students, most supervised by Solow. ${ }^{10}$

\section{Optimal Growth}

How should we evaluate economic policy in a growth model? What could it mean to target optimal growth? As we have seen, the versions of the neoclassical growth model available

\footnotetext{
${ }^{10}$ Solow supervised the doctoral dissertations on growth of Ronald Findlay (1960), Peter Diamond (1963), Eytan Sheshinski (1966) Joseph Stiglitz (1966), George Akerlof (1966), William Nordhaus (1967a) and Avinash Dixit (1968a). Samuelson supervised David Levhari (1964) and Edwin Burmeister (1965).
} 
around 1960 provided no lever for the rate of economic growth in the long run. Policy - to the degree that it could influence the rate of investment, savings, or population growth- could influence capital deepening. The question of optimal growth in the long run could, therefore, be turned into a question not about the rate of growth but about the best capital-labor ratio. Phelps (1961) proposed the "golden rule of growth.” Taking consumption per capita as the desideratum, Phelps showed that it was maximized when the capital-labor ratio was set to a point such that the rate of profit (identified with the marginal product of capital or the real rate of interest) equaled the natural rate of growth (i.e., the sum of the rates of growth of population and technical progress). The academic year 1962-63 was a “golden year for Golden-Rulers at MIT” . . . Christian von Weizsäcker, Christopher Bliss, and others “proved all kinds of theorems” in Economics 14.123 (Advanced Economic Theory) - the course taught jointly by Solow and Phelps (Samuelson 1965b, p. 487, fn.).

From Samuelson’s (1964, p. 748) perspective, the golden rule was a special case of von Neumann's theorem that a self-reproducing, linear economy has a balanced maximum growth configuration or turnpike, along which the real rate of interest equals the rate of growth. In their work on linear programming, Dorfman, Samuelson and Solow (1958, pp. 329-34) had proved the turnpike conjecture: given the objective of maximizing the size of a capital stock for a given constant technology at some future date, the efficient growth path will run close to von Neumann's turnpike for most of the planning period.

The constraints on the planning problem are "exactly like a turnpike paralleled by a network of minor roads” (Dorfman et al. 1958, p. 331). The metaphor of the turnpike provides the intuition. The mix of output currently produced is some location in the country. The higher quantity of output targeted in the future with a different balance of products is some other 
location. To move from one location to the other, there may be a direct route. However, it may be more efficient to take the local road to the turnpike (i.e., to first shift the mix of products to the mix that characterizes the fastest von Neumann balanced growth path), to drive along the turnpike (i.e., to grow along the fastest balanced growth path) and, then, to exit close to the final destination, taking the local roads to our preferred location (i.e., at some optimal point shifting the mix of products to the final desired mix). Dorfman et al. (1958, p. 331) regarded the turnpike as offering a "real normative significance for steady growth.” Its significance, however, is for the optimal rate of transition and not for the optimal rate of long-run growth.

The normative target of Phelps’s golden-rule analysis, maximum consumption per capita, is straightforward but not economically natural. In a world with capital, there is a tradeoff between consumption today and consumption tomorrow over which different preferences are possible. It is most naturally an intertemporal utility maximization problem. This problem had been solved - though not in the context of a growth model - in Frank Ramsey’s (1928) work on optimal saving. Ramsey’s paper was well known to Samuelson, Solow, and others at MIT. Intertemporal utility maximization in a growth model was technically challenging. The translation from the Russian of the book on optimal control by L.S Pontryagin and his associates in 1962 immediately changed the landscape of growth economics - not only at MIT but elsewhere (Wulwick 1995, pp. 418-21). Edwin Burmeister, a student in Economics 14.123, recalled that the subject of the lecture on 12 December 1962 was Optimality Problems in Capital Theory:

We were shown how to use the Maximum Principle of Pontryagin to solve the famous Ramsey problem of optimal saving over time. In this lecture we covered essentially everything that is contained in the famous David Cass paper that was not published until July 1965! [Burmeister 2009, p. 38] 
At Stanford, Hirofumi Uzawa and his students, David Cass and Karl Shell quickly incorporated Pontryagin's methods into their own work on the theory of optimal growth. Shell, who was a member of the faculty from 1964 to 1968, organized a seminar on optimal economic growth at MIT in 1965-66. The seminar included presentations from several young MIT scholars.

Pontryagin’s optimal control theory involved the maximization of a Hamiltonian equation at each time, from which differential equations describing optimal dynamic paths could be derived. A volume of essays edited by Shell (1967a) demonstrated the application of Pontryagin's technique to a variety of issues in the theory of optimal economic growth, including growth with technical progress. The theory of optimal growth was seen as "normative dynamic macroeconomics” (Intriligator 1969, p. 116) and found its way into Solow’s (1970 chs. 5 and 6) retrospective lectures and Burmeister and Dobbel’s (1970, ch. 11) early graduate textbook.

Reactions to Shell’s conference volume, however, were mixed. Frank Hahn (1968, p. 561) complained that the enthusiasm for the new technique often led to neglecting the economics of the models: "Very little is said by any of the authors about the choice of the maximand. Indeed there is something of an unseemly haste to get down to the Hamiltonian.”"11

Samuelson's original vision of applying the neoclassical synthesis to growth models had invoked macroeconomic policy, but the literature on optimal growth focused in the main on the appropriate rates of investment - often with the artificial, but convenient invocation of a central

\footnotetext{
${ }^{11}$ Hahn was one of the participants at another conference (and month-long workshop) on optimal growth, led by Arrow in Stanford in July 1965 (see Arrow Papers, Box 28; McKenzie 1999). Conference participants included also Lionel McKenzie, Roy Radner, Koopmans, Mirrlees, Uzawa and Sheshinski (the only one from MIT), among others. Sheshinski presented a joint paper (with Burmeister) about reswitching. Warsh (2006, pp. 155-56) has reported that optimal growth papers by some MIT young scholars were coldly received at the conference. Apparently, those papers were not included in the Stanford conference program, and were later discussed at the MIT 1965-66 seminar run by Shell.
} 
planner. MIT economists Duncan Foley and Miguel Sidrauski $(1970,1971)$ turned back to the original problem by constructing a growth model in which consumption and investment goods were produced in distinct sectors and in which the effects of alternative fiscal and monetary policies on the non-steady state growth path of flow and stock variables could be investigated. Foley and Sidrauski (1971) based their chapter 15 on an article co-authored with Shell (Foley, Shell, and Sidrauski 1969). In order to achieve the optimal growth paths for consumption and investment while maintaining stable consumer prices, fiscal and monetary policies must induce the capital goods sector to produce investment goods at the optimal rate. The framework presupposes policies operating through private markets, as in the neoclassical synthesis, rather than through a central planner, as in the most common understanding of Ramsey’s (1928) original framework for analyzing optimal savings. ${ }^{12}$

\section{Technical Progress}

The first item on the agenda for growth theory at MIT had been optimal growth. The focus turned out to be on optimal level of the capital-output ratio; it did nothing to advance normative guidance with respect to the rate of steady-state growth. The second item on the agenda, while mainly aiming to open the black box of exogenous technical progress, also offered hope of connecting the rate of growth with economic policy and, so, vindicating Samuelson's initial optimism about the scope of economic policy.

\footnotetext{
${ }^{12}$ Whether Ramsey intended the single utility function of an immortal individual in his model to refer to a central planner or to a "representative agent" in the private economy is disputed among historians; see Duarte (2010), pp. 126-130). An alternative demographic structure (to both Solow's and Ramsey's models) was put forward by Samuelson's (1958) overlapping generations model, later extended to growth economics by Peter Diamond (1965). That was not part of Diamond's 1963 thesis; it was written when he was teaching public finance at Berkeley in 1964. In 1966 Solow recruited Diamond to MIT.
} 
The idea of disembodied technical progress was not a natural one; it found its way into Solow’s (1957) paper only as a strategy for measuring as a residual an economic characteristic that was otherwise hard to observe. ${ }^{13}$ The idea that technical progress was an economically explicable element of the growth process, of course, went back to Adam Smith (1776, book I, ch. I), and it found a powerful modern expression in Joseph Schumpeter's ([1911] 1934, 1942) analysis of capitalist development with its emphasis on “creative destruction.” Both Solow and Samuelson had been students of Schumpeter at Harvard. Samuelson credited Schumpeter as an important influence. Solow - perhaps because he first encountered Schumpeter some ten years after Samuelson, at which point Schumpeter's interests were no longer primarily theoretical was less favorably impressed. In a comment on Samuelson's papers with Schumpeterian themes, Solow (1983, p. 185) recalled that "Schumpeter was a teacher of mine, too ... but he either meant less to me or I lack adequate intellectual piety.” Samuelson (1964, p. 742) suggested that Solow's growth model vindicated Schumpeter's argument that innovations were the engine of growth; yet, he did not attempt to use Schumpeter's notion of creative destruction to model the pace of technological progress.

Biased technical progress had been a traditional topic in production and distribution theory since the 1930s (e.g., Hicks 1932. Cf. Samuelson 1964, pp. 738-739; Solow 2010, section 3). Still, technical change itself had not been modeled formally. Discussions with von Weizsäcker, who visited MIT in 1962-1963, and Charles Kennedy, who presented a seminar in the department in May 1964, prompted Samuelson to address the notion of induced factor bias in invention in some detail.

\footnotetext{
${ }^{13}$ It is an old strategy; see Hoover and Dowell (2002) and Hoover and Duarte (2012).
} 
Kennedy (1964) advanced the concept of a trade-off between capital-augmenting and labor-augmenting technical progress, which could be represented as an invention-possibility frontier - a concave curve representing the constraint faced by entrepreneurs in the choice of the direction of technical progress. Samuelson (1965a, 1966) incorporated Kennedy’s curve into a neoclassical growth model. He showed that, if the elasticity of substitution is less than one, there exists a stable balanced-growth path (or "Golden Age”) characterized by Harrod-neutral (i.e., labor-augmenting) technical progress and constant relative factor shares in output. Unlike the usual case in which Harrod-neutral technical progress is built in by assumption, it arises endogenously in Samuelson's model from the working of market forces (see Wan 1971, ch. 7, section 2). Samuelson found the results compelling enough that he added a note to the seventh edition of Economics, claiming that the theory of induced technical progress met the challenge of explaining all the basic trends of capitalism, including increasing capital-labor ratio and increasing real wages, as well as the near constancy of the capital-output ratio and interest rates (Samuelson 1967, p. 721, n. 17; see also 1966, pp. 447-48).

As with the theory of optimal growth, the younger generation did the lion's share of the work to elaborate the theory of technical progress. It mainly fell into three interrelated streams: i) the role of publicly supported research and development; ii) the role of "learning by doing"; and iii) the role of privately motivated research and development.

William Nordhaus addressed the role of government in promoting technical progress (Nordhaus 1967a, 1967b; 1969a, ch. 6). Following Uzawa (1965), he assumed that central planners can allocate a fraction of the labor force to research or education and, thereby, push out the invention-possibility curve, which in turn determines the rate of technical progress. A central planner can choose the rate capital accumulation and the rate and direction of technical progress 
to maximize present discounted value of consumption per capita. Having solved the central planner's problem, Nordhaus asked whether the results would carry over to a competitive market economy, only to conclude that “[c]ompetition will break down” because of increasing returns and that technical progress in his model is compatible with competition only if it is exogenous (Nordhaus 1967b, pp. 64-65; 1969a, pp. 111-13). Nordhaus had assumed that the inventionpossibility curve was governed by a fixed quantity of research expenditures, so that the level of research is independent of the size of the firm. If there are constant returns to scale in capital and labor, average costs decline with increasing output. If knowledge is also recognized as a distinct input into production, the production function, which is homogenous of degree one in capital and labor, must be homogenous of degree greater than one (i.e., must exhibit increasing returns) in all factors.

The theme of the December 1965 meetings of the American Economic Association (AEA) was “knowledge, production and innovation.” The AEA president, Fritz Machlup, asked Solow to arrange a session on capital and technical progress; and Solow, in turn, invited papers from Shell, Richard Nelson and Phelps, and Zvi Griliches and Dale Jorgenson (letter from Solow to Machlup, Solow Papers, Box 58). Shell (1966) presented a new model of endogenous technical change based on the assumption that knowledge is a government-funded, pure public good that acts as an input in the production functions of individual firms. Shell adopts Arrow's (1962b) view of knowledge as characterized by "inappropriability” and "indivisibility”: while it may be costly to produce a new idea, as Shell (1966, p. 63) put it, "knowledge can be used by many economic units without altering its character," with but a "small cost of transmission in comparison to the cost of production” (see also Meade, 1968, ch. 9; Nordhaus 1969b, pp. 18-19). Knowledge as a public good, free at the margin, implies increasing returns to scale (Shell 1966, 
p. 64). In such as case, according to Euler's theorem, if factors receive the value of the their marginal products, payments to conventional factors would exhaust output, leaving no compensation for creating new technology. As with other cases of public goods, the private sector would not receive sufficient incentive to support the socially optimal quantity of technological knowledge (Shell 1973, p. 80; Kaldor 1961, p. 206).

Shell (1966) showed that his model also displayed unanticipated dynamics. In the model, the rate of growth of technical progress $(A)$ depends positively on the share of output devoted to invention and on the success rate of inventions (less that 100 percent), as well as negatively on the “decay in technical knowledge . . . because of the imperfect transmission of technical information from one generation of the labor force to the next” (p. 63). The rate of change of the capital-labor ratio $(k)$ depends positively on the savings (or investment) rate and negatively on the share of output devoted to invention and on the ordinary depreciation of capital.

Shell shows that the steady state of the model can be characterized as the intersection of two curves in technology/capital-output-ratio $(A / k)$ space: one is the vertical locus at $k_{0}$ of all points for which $\dot{A}=0$ and the other is the upward-sloping locus of all points for which $\dot{k}=0$. The dynamics can be characterize as follows: if the economy finds itself at any point lying above $\dot{k}=0$, the capital-labor ratio increases (i.e., capital deepens) and, at any point below, it falls; if the economy finds itself at any point to the left of $\dot{A}=0$, the level of technology falls and, at any point to the right, it rises. These dynamics imply that almost every point in $A / k$ space is unstable in the sense that, if the economy starts at that point, it will diverge from the steady state. However, there is a precise locus of points running from the northwest to the southeast of the $A / k$ space, for which the combination of forces is exactly calibrated to move the economy toward the steady state: this is the saddle path, which Shell (1967b, p. 77) characterizes as 
"razor's edge.” If the economy starts below the saddle path, it decays; if it starts above, it explodes.

The saddle-path stability of Shell's model - that is, the fact that it was almost everywhere unstable - was a surprise, since the neoclassical growth model in its simplest incarnation was itself stable (Shell 1967b, p. 77, n.13). Most commentators found the result unwelcome (see e.g. Conlisk 1967). ${ }^{14}$ It was a replay of the kind of instability that had caused the Harrod-Domar model to be widely regarded as unattractive. Shell’s discussant, Kazuo Sato (1966), suggested that the additional assumption of diminishing returns in the production of technology might circumvent the implication that an economy above the saddle path would grow without limit.

In contrast, Shell embraced the result: global stability was an "interesting property,” but it should not be considered “essential” for a growth model. Shell cited Maruyama’s (1960) characterization of social systems as fundamentally morphogenic (interpreted as constantly developing their structural forms) as opposed to morphostatic (maintaining a stable form). Shell's model predicted that, whereas rich countries tend to grow at increasing rates, poor countries tend to decay, and might need a Big Push (Shell 1967b, p. 79). Once again, we see an effort to bring the methodological preference for precision and simple models of the Economics Department to the substantive concerns of CENIS, going back to the debate between Rostow and Solow at the Konstanz conference.

Shell's assumption to his point had been that the economy was competitive, although the share of output devoted to invention was an exogenous function. He also considers the analysis from the point of view of a central planner. Either way, technical progress is the intended output

\footnotetext{
${ }^{14}$ Others, however, found Shell's saddle point instability attractive. Philip Neher (1971, pp. 199-205) compared it to the take-off and big push approaches of Rosenstein-Rodan and others.
} 
of a research sector. Levhari (1964; 1966a, b) and Sheshinski (1966, 1967a, b) took a different approach, building on Arrow’s (1962a) notion of learning by doing. Based on, among other things, empirical evidence that productivity in the airframe industry increased regularly with the number of airframes produced, Arrow had suggest, more generally, that technological progress was an increasing function of cumulative gross investment - an unintended, though welcome byproduct of production.

If learning by doing were pervasive, then the economy as a whole would display increasing returns to scale. In contrast to typical cases, these increasing returns would be compatible with perfect competition, because the private marginal productivity of capital is less than its social marginal productivity -- learning provides a positive externality uncompensated by the market. Since it did not threaten perfect competition, learning by doing was easy to slot into the neoclassical growth model (see Solow 1967, pp. 38-41).

While Arrow had used a vintage approach with fixed coefficients, Levhari’s and Sheshinski's models featured disembodied technical progress with variable coefficients. The key to Sheshinski's model is the learning function in which technology $(A)$ at any time $t$ is related to the sum of all past gross investment $(G)$, so that $A(t)=[G(t)]^{\alpha}$, where $\alpha, 0<\alpha<1$, is the elasticity of the level of technology to past gross investment. In a model with no depreciation of capital, technology can be expressed more simply as a function of the stock of capital $(K): A(K)$. In that case, the solution for the balanced rate of growth of income per capita $(g)$ is also very simple: $g=n /(1-\alpha)$, where $n$ is the rate of population growth.

The steady-state rate of growth in both Arrow’s (1962a) and Sheshinki’s (1967a) models is, thus, a multiple of the growth rate of population. When population stops growing, technology stops progressing. The linkage between technology and population is the result of diminishing 
returns to cumulative investment in the generation of knowledge - i.e., to $\alpha<1$. As Hahn and Matthews (1964, p. 846) put it: economic growth can be maintained only if "population growth provides a source of increase in output and experience additional to that built into the investment learning process itself.” As in the basic neoclassical growth model, a change in the savings rate affects only the level of output per capita and not the steady-state rate of growth.

Solow discussed Arrow’s model in detail in Economics 14.123 (Advanced Economic Theory) in 1962 (Burmeister 1962). He extended the model to the "linear" case in which $\alpha=1$ (i.e., the case in which there are no diminishing returns to accumulated production experience) a case that Arrow (1962a, p. 159) had mentioned but not explored. Burmeister’s (1962) records in his class notes: “now the savings rate determines the rate of growth.” Solow (1967) did not refer to the linear case or to that result in his survey of the theory of production; but he came back to the matter thirty years later when the consequences of linearity for growth theory and policy had become a key issue in a revived growth economics (Solow 1997).

In the summer of 1965, Uzawa invited a group of graduate students and younger professors from MIT to work with him at a seminar on growth in Chicago - special attention was to be paid to the problem of incorporating endogenous technical change into growth models (Stiglitz 1990, p. 63, n. 12; Warsh 2006, p. 155). The group included, among others, Shell, Stiglitz, Nordhaus, Sheshinski, and Akerlof. With the exception of Nordhaus (1967b), none of the participants from MIT, picked up on Uzawa’s (1965) own model of technical progress, which located the source of technical progress in human capital subject to nondecreasing returns. Uzawa wrote to Solow:

I have been enjoying my association with the group of MIT students. We have been working on a couple of projects on economic growth, although none of us have come up 
with anything concrete. I have been particularly impressed by Joe Stiglitz. [letter, Uzawa to Solow, 18 June 1965, Solow Papers, Box 61] ${ }^{15}$

Stiglitz spent the following academic year at Cambridge University, where he presented a paper titled “Towards an Endogenous Theory of Technological Change” (letter, Stiglitz to Solow, 2 November 1965, Solow Papers, Box 60). That paper did not, however, form part of Stiglitz’s doctoral dissertation and was never published.

Some of the growth models that we have considered to this point were conceived of as applying to a planned economy and some to a competitive economy; but as Shell observed in the conclusion to his AEA conference paper:

the recent contribution of Kennedy warns us that additions to technical knowledge should not be thought of as increasing efficiency in any specified way. That is, the "bias of technical progress," whether in a stylized [competitive] economy or in a planned economy, should be a subject for economic decision. [Shell 1966, p. 68]

Nordhaus (1969b), who had already addressed other aspects of technical progress in his doctoral dissertation in 1967, was the first MIT economist to take up the Kennedy/Shell challenge and to model technical progress as guided by the optimizing decisions of economic agents. Nordhaus focused on the role of an inventor, who has a monopoly over his invention for a limited period of time (a patent). The "crucial” and "questionable” assumption of the model is the relationship between the inventive input and the rate of technical change (Nordhaus 1969b, p. 21). The rate of growth of technology was modeled as directly related to the number of inventions and inversely related the level of technology. He assumed that there were diminishing returns to the number of inventions.

Nordhaus’s equation for the rate of technical progress has the “peculiar, nonneoclassical feature” that technology will stagnate if population is stationary (p. 23). The peculiar feature is

\footnotetext{
${ }^{15}$ In an undated memo to L. McKenzie, Uzawa wrote that "I am afraid this [Chicago 1965] seminar might not have had any particular impact upon the students who visited from MIT” (Solow Papers, Box 58).
} 
the result of diminishing returns in the knowledge function. It implies that the number of inventions can increase only if income is growing faster than the rate of technical progress. As in the models of learning by doing, this feature is attributable to the fact that economies of scale accrue to the economy as a whole. Increasing returns are consistent with competition in the product market because "information is temporarily monopolized” through patents. Nordhaus presented his paper at the AEA meetings in December 1968 with Domar and Stiglitz serving as discussants. Domar (1969, p. 44) complained that such concepts as a long-run balanced growth path and a termination of the inventive process because of the end of population growth "do not really belong to [Nordhaus’s] Schumpeterian world.” Stiglitz (1969, p. 46) defended Nordhaus’s model and the notion of a stable production function for technology. Arrow (1969, p. 34) had attacked such as stable function in his own presentation in the same session.

\section{The Ebb Tide of MIT Growth Theory}

For the fifteen years after Solow and Swan introduced the neoclassical growth model, growth economics was a dominant field, and MIT Economics Department was its beating heart. E. Roy Weintraub (1991) has described the process through which a field comes to be defined and delimited as a process of stabilization. Growth economics provides a perfect case study. From the 1930s until the advent of the neoclassical growth model in 1956, growth economics had been exploratory in character, mixing a variety of analytical strategies and substantive concerns in a heterogeneous brew. By the early 1950s, development economists had begun to adopt the Harrod-Domar model as a standard approach. The neoclassical growth model challenged the analytical framework of the Harrod-Domar model, while Solow’s (1957) empirical investigation based on the neoclassical growth model challenged the widespread understanding that economic 
growth was principally the result of investment in physical capital. The next fifteen years can be thought of as a contest between frameworks (e.g., neoclassical vs. Harrod-Domar, and neoclassical vs. Cambridge U.K.; see Backhouse on the “other Cambridge”, this volume) and a process of delimiting the range of applications for different approaches. This is illustrated very well by the interests and approaches of the MIT Economics Department and CENIS. The process of stabilization was, in part, a division of labor between the methodological contribution of the department (simple, precise, formal models) and the substantive, empirical interests of the development economists and, in part, a definition of domains, with development economics and the growth economics of the already developed countries coming to be defined as distinct and separable problems.

The process of stabilization throws up some characteristic markers. Already by the mid1960s, Hahn and Matthews (1964) had published a famous and influential survey article - which, in fact, was issued as part of a hardcover book as well. At the same time, neoclassical growth economics became sufficiently intellectually secure that it was incorporated into Samuelson's undergraduate textbook. By the end of the 1960s, a canon had been established: In 1968-69 Solow's Radcliffe Lectures at the University of Warwick offered a consolidated account of the state of growth economics (Solow 1970). ${ }^{16}$ Anthologies of important articles on growth began to be published (Stiglitz and Uzawa 1969, Sen 1970). And the appearance of the first graduate textbook (by two MIT PhDs) Burmeister and Dobbel’s Mathematical Theories of Economic Growth (1970) began to standardize instruction for the next generation (see also Wan 1971). Growth economics had never been an exclusively MIT project, but many of these stabilizing

\footnotetext{
${ }^{16}$ Solow's Radcliffe Lectures follow very closely a set of lectures that he developed for his MIT course (Solow 1966).
} 
activities were centered at MIT, and MIT students and affiliates rapidly filled the ranks of economics departments around the world (see Svorencik, this volume).

The future looked bright. Solow’s foreword to Burmeister-Dobell’s (1970, pp. viii-ix) graduate textbook suggested that growth theorists faced a busy agenda of important problems. Yet, in retrospect, the end of the 1960s marked the high tide of growth economics. Just as the field appeared to stabilize, it also began to ebb as a preeminent research program. Why?

First, the political climate had changed radically. The Cold War and growthmanship of 1960 had yielded to the first Earth Day and environmentalism of 1970. The publication of the Club of Rome's report, The Limits to Growth - the product of a research group in MIT's Sloan School of Management - exemplified the shift in mood (Meadows et al. 1972; see also Arndt 1978; Collins 2000). Growth was increasingly viewed not as the optimistic project of "lifting all boats” but as a threat to life itself. ${ }^{17}$

A second reason for the ebbing of growth economics was the business cycle. The apparent success of macroeconomic management in the Kennedy and Johnson administrations bolstered Solow optimism: "short-run macroeconomic theory is pretty well in hand" (Solow 1964, p. 103 - a paper originally presented to a conference in 1962). The business cycle expansion that started in 1961 proved to be the longest in U.S. history up to that time. Economists began to ask, “Is the business cycle obsolete?” (Bronfenbrenner1969). Such

\footnotetext{
${ }^{17}$ The Economics Department did not simply capitulate to their colleagues in the Sloan School. Drawing on his well-developed expertise in the characteristics of the kind of multi-equation linear models that informed the Limits to Growth, Solow (1973) argued that the crash states that it predicted were built into its modeling assumptions independently of the empirical facts of the world and that it ignored basic economics: as resources became scarcer, their prices would rise leading both to economies in use and substitution into alternative factors of production. Solow's criticisms of the Harrod-Domar model found a new target. Nordhaus and Tobin (1972) and Samuelson (1976, pp. 814-817) similarly rejected the doomsday scenarios and reaffirmed the possibility of continued growth. Nordhaus's shift into natural resource economics and climate change was a reflection that externalities are an important phenomenon, but whereas his earlier work on technical progress was on positive externalities, the later was on negative externalities (correspondence with the authors, 18 May 2013).
} 
questions are leadings indicators of a crash: the boom ended in December 1969. The commodity price boom, the first oil crisis of 1973, Nixon's price controls, and the perceived failure of “Keynesian” macroeconometric models to account for the stagflation of the early 1970s moved short-run macroeconomic analysis to the fore. In the sixth edition of Economics, Samuelson (1964, p. 722) had added the sentence, “The key word in most economic discussions these days is 'growth'." In the ninth edition, he not only dropped the sentence but suggested that a short course could omit the chapter on growth altogether (Samuelson 1973, p. 731).

A third reason for the ebbing of growth economics was frustration that its early promise precise formal models that would illuminate policy - had not been redeemed. Research strategies ran up against a variety of intellectual barriers. For example:

- For all its supposed importance and for all the effort put into modeling it, Solow's (1970, p. 76) concluded that "very little is known about the exact connection between research expenditure and actual technological progress.” Indeed, endogenous growth models put forward by Shell, Nordhaus, Levhari and Sheshinski at MIT in the 1960s were largely invisible in the renditions of growth economics offered by Solow (1970) and BurmeisterDobell (1970).

- One of the supposedly great advantages of the neoclassical growth model over the Harrod-Domar model was that it displayed a stable steady-state growth path. Thus, when saddle-point instability was first discovered it was thought to be "potentially fatal” to the whole theory (Dixit 1990, p.6).

- Referring to the development of endogenous growth models, Stiglitz (1990, p. 55) recalled the "stumbling blocks" related to nonconvexitites in the production function: “We knew how to construct models that 'worked,' but we felt uneasy making special 
assumptions" to guarantee the existence of a steady state. Sheshinski wrote that "we already knew in 1965 that a production function linear in capital leads to endogenous growth rate. But this was unattractive because of the knife-edge properties (lack of stability)” (correspondence with the authors, 3 March 2013). Nonconvexities are incompatible with perfect competition, but there were no aggregative models of imperfect competition available in the 1960s (cf. Nordhaus 1969a, p. 113). ${ }^{18}$

Finally, and related to the third reason, a point is reached in the history of any field where - for some time, at least - it faces diminishing returns. Hahn and Matthews had detected the signs early:

While not disparaging the insights that have been gained, we feel that in these areas the point of diminishing returns may have been reached. Nothing is easier than to ring the changes on more and more complicated models, without bringing in any really new ideas and without bringing the theory any nearer to casting light on the causes of the wealth of nations. The problems posed may well have intellectual fascination. But it is essentially a frivolous occupation to take a chain with links of very uneven strength and devote one's energies to strengthening and polishing the links that are already relatively strong. [Hahn and Matthews 1964, p. 890]

Six years later, Solow (1970, p. 105) still argued that the effort was "not a game.” Yet, by 1978 he had thrown in the towel, noting the "definite signs that [growth theory] is just about played out ... Growth theory is now an unpromising pond for an enterprising theorist to fish in” (quoted in Solow 1991, p. 393).

The early 1970s did not prove to be the end of growth economics at MIT or elsewhere. Work continued on growth theory, albeit at a lower level. Development economists and specialists in productivity and technology continued to advance empirical studies. But for the

\footnotetext{
${ }^{18}$ Solow (1956, pp. 71-72) considered the possibility that the marginal product is bounded away from zero (and labor, therefore, is not essential for production). In this case, similarly to the so-called $A K$ growth models of the 1990s, the long-run rate of growth becomes endogenous in respect to savings behavior. Such a "pathological" possibility was discussed by Burmeister and Dobell (1970, pp. 33-34), but dismissed as empirically implausible.
} 
time being, growth economics was no longer the field in which stellar reputations were forged.

Yet, intellectual tides are like natural tides: they flow as well as ebb. Growth theory revived in the mid-1980s in the work of Paul Romer (1986) and Robert Lucas (1988), as well as many others. They addressed many of the same issues that had animated the growthmen of the 1960s, but the center of growth economics was no longer the banks of the Charles River but the shores of Lake Michigan.

\section{References}

Akerlof, G. 1966. Wages and capital. PhD thesis. MIT.

Arndt, H.W. 1978. The rise and fall of economic growth. Melbourne: Longman Cheshire.

Arrow, K. 1962a. The economic implications of learning by doing. Review of Economic Studies. 29: $155-73$.

Arrow, K. 1962b. Economic welfare and the allocation of resources for invention. In The rate and direction of inventive activity: economic and social factors, pp. 609-25. Princeton: Princeton University Press for NBER.

Arrow, K. 1969. Classificatory notes on the production and transmission of technological knowledge. American Economic Review. 59: 29-35.

Boianovsky, M. 2010. A view from the tropics: Celso Furtado and the theory of economic development in the 1950s. History of Political Economy. 42: 221-66.

Boianovsky, M. and K.D. Hoover. 2009a. The neoclassical growth model and twentieth-century economics. In Boianovsky and Hoover 2009b, pp. 1-23.

Boianovsky, M. and K.D. Hoover (eds.). 2009b. Robert Solow and the development of growth economics. Annual supplement to vol. 41 of History of Political Economy. Durham: Duke University Press.

Bronfenbrenner, M. (ed.). 1969. Is the Business Cycle Obsolete? New York: Wiley.

Burmeister, E. 1962. Lecture notes, Solow’s Advanced Economic Theory 14.123. Burmeister Papers, Duke Archives.

Burmeister,E. 1965. Stability and causality in two-sector models of economic growth. PhD thesis. MIT.

Burmeister, E. 2009. Reflections. In Boianovsky and Hoover (eds.) 2009b, pp. 3543.

Burmeister, E. and A. R. Dobell. 1970. Mathematical theories of economic growth. London: Macmillan. 
Chakrvarty, S. 1969. Capital and development planning. Cambridge (Mass.): MIT Press.

Collins, R.M. 2000. More: the politics of economic growth in postwar America. New York: Oxford University Press.

Conlisk, J. 1967. A modified neoclassical growth model with endogenous technological change. Southern Economic Journal. 34: 199-208.

Diamond, P. 1963. Essays on optimal economic growth. PhD thesis. MIT.

Diamond, P. 1965. National debt in a neoclassical growth model. American Economic Review. 55: $1126-50$.

Diamond, P. (ed.). 1990. Growth/Productivity/Unemployment: Essays to celebrate Bob Solow's birthday. Cambridge (Mass): MIT Press.

Dimand R. W. and B. J. Spencer. 2009. Trevor Swan and the neoclassical growth model. In Boianovsky and Hoover (eds.) 2009b, pp. 107-126.

Dixit, A. 1968a. Development planning in a dual economy. PhD thesis. MIT.

Dixit, A. 1968b. Optimal development in the labour-surplus economy. Review of Economic Studies. 35: 23-34.

Dixit, A. 1973. Models of dual economies. In Mirrlees and Stern (eds.) 1973, pp. 325-52.

Dixit, A. 1990. Growth theory after thirty years. In Diamond (ed.)1990, pp. 4-22.

Domar, Evsey D. (1946) “Capital Expansion, Rate of Growth, and Employment,” Econometrica, 14 (2), 137-147.

Domar, E.D. 1957. Essays in the theory of economic growth. New York: Oxford University Press.

Domar, E.D. 1961. On the measurement of technological change. Economic Journal. 71: 709-29.

Domar, E.D. 1969. Discussion. American Economic Review. 59: 44-46.

Dorfman, R., P. Samuelson and R. Solow. 1958. Linear programming \& economic analysis. Tokyo: McGraw-Hill Kogakusha.

Duarte, P.D. 2012. Beyond Samuelson's chapter on Ramsey. History of Economic Ideas. 18: 121-159.

Duarte, P.D. and K.D. Hoover. 2012. Observing Shocks. History of Political Economy 44(supplement): 226-249.

Findlay, R. 1960. Essays on some theoretical aspects of economic growth. PhD thesis. MIT.

Foley, D.K., K. Shell and M. Sidrauski. 1969. Optimal fiscal and monetary policy and economic growth. Journal of Political Economy. 77: 698-719.

Foley, D.K. and M. Sidrauski. 1970. Portfolio choice, investment, and growth. American Economic Review. 60: 44-63.

Foley, D.K. and M. Sidrauski. 1971. Monetary and fiscal policy in a growing economy. New York: Macmillan. 
Hahn, F.H. 1968. Review of Shell (1967a). American Economic Review. 58: 561-65.

Hahn, F.H. and R.C.O. Matthews. The theory of economic growth: a survey. Economic Journal. 74: 779-902.

Halsmayer, V. and K.D. Hoover. 2013. Solow's Harrod: Transforming Cyclical Dynamics into a Model of Long-run Growth. Center for the History of Political Economy at Duke University, working paper.

Harrod, Roy F. (1939) “An Essay in Dynamic Theory,” Economic Journal, 49 (193), 14-33.

Harrod, Roy F. (1948) Towards a Dynamic Economics. London: Macmillan.

Hartley J.E., K.D. Hoover, and K.D. Salyer. 1997. The limits of business cycle research: Assessing the real-business-cycle model. Oxford Review of Economic Policy. 13: 34-54.

Hartley J.E., K.D. Hoover, and K.D. Salyer. 1998. The limits of business cycle research. In Hartley, Hoover, and Salyer (eds.) Real business cycles: A reader. London: Routledge, pp. 342.

Hoover, K.D. and M.E. Dowell. 2002. Measuring causes: Episodes in the quantitative assessment of the value of money. History of Political Economy, 33 (Annual Supplement): 137-161.

Intriligator, M.D. 1969. Review of Shell (1967a). Journal of Business. 42: 116-17.

Kaldor, N. 1961. Capital accumulation and economic growth. In The theory of capital, pp. 177222, ed. by F. Lutz. London: Macmillan.

Kennedy, C. 1964. Induced bias in innovation and the theory of distribution. Economic Journal. 74: 541-47.

Kindleberger, C. [1958] 1965. Economic Development, $2^{\text {nd }}$ edition. New York: McGraw-Hill.

Levhari, D. 1964. Essays on optimal economic growth. PhD thesis. MIT.

Levhari, D. 1966a. Extensions of Arrow’s learning by doing. Review of Economic Studies. 33: 117-31.

Levhari, D. 1966b. Further implications of learning by doing. Review of Economic Studies. 33: 31-38.

Lewis, A. 1954. Economic development with unlimited supplies of labour. Manchester School. 22: 139-91.

Lodewijks, J. 1991. Rostow, developing economies, and national security policy. In Economics and national security, pp. 285-310, ed. by C.D. Goodwin. Annual supplement to History of Political Economy, v. 23. Durham: Duke University Press.

Lucas, R.E., Jr. 1988. On the mechanics of economic development. Journal of Monetary Economics. 22: 3-42.

Marglin, S. 1967. The rate of interest and the value of capital with unlimited supplies of labour. In Shell (ed) 1967a, pp. 141-63.

Maruyama, M. 1960. Morphogenesis and morphostasis. Methodos. 12: 251-96. 
McKenzie, L. 1999. The first conferences on the theory of economic growth. Rochester Center for Economic Research. Working Paper \# 459.

Meade, J. [1961] 1962. A neo-classical theory of economic growth, $2^{\text {nd }}$ edition. London: Unwin.

Meade, J. 1968. The growing economy. London: Allen \& Unwin.

Meadows, D.H., D.L. Meadows, J. Randers, and W. W. Behrens. 1972. The limits to growth. New York: Universe.

Mirrlees, J.A. and N.H.Stern (eds.). 1973. Models of Economic Growth. Proceedings of a conference held by the International Economic Association. London: Macmillan.

Neher, P. 1971. Economic growth \& development: a mathematical introduction. New York: John Wiley \& Sons.

Nordhaus, W.D. 1967a. A theory of endogenous technological change. PhD thesis. MIT.

Nordhaus, W.D. 1967b. The optimal rate and direction of technical change. In Shell (ed) 1967a, pp. 53-66.

Nordhaus, W.D. 1969a. Invention, growth, and welfare. Cambridge (Mass.): MIT Press.

Nordhaus, W.D. 1969b. An economic theory of technical change. American Economic Review. 59: 18-28.

Nordhaus, W.D. and J. Tobin. 1972. Is growth obsolete? In Economic research: retrospect and prospect vol. 5: economic growth, pp. 1-80. New York: NBER.

K.A. Pearce and K.D. Hoover. 1995. After the Revolution: Paul Samuelson and the Textbook Keynesian Model. History of Political Economy 27(supplement): 183 - 216.

Phelps, E.S. 1961. The golden rule of accumulation: a fable for growthmen. American Economic Review. 51: 638-43.

Phelps, E.S. 1962. The new view of investment: a neoclassical analysis. Quarterly Journal of Economics. 78: 548-67.

Pontryagin, J.S. et al. 1962. The mathematical theory of optimal processes, tr. by K.W. Trirogoff. New York: International Publishers.

Ramsey, F.P. 1928. A mathematical theory of saving. Economic Journal. 38: 543-59.

Romer, P.M. 1986. Increasing Returns and Long-run Growth. Journal of Political Economy. 94: 1002-37.

Rosenstein-Rodan, P. 1943. Problems of industrialization of eastern and southeastern Europe. Economic Journal. 53: 202-11.

Rosenstein-Rodan, Paul. 1957. Notes on the theory of the "big push”. Centre for International Studies, MIT.

Rosenstein-Rodan, P. 1961. Notes on the theory of the "big push". In Economic Development of Latin America, pp. 57-67, ed. by H.S. Ellis and H.C. Wallich. London: Macmillan.

Rostow, W.W. 1956. The take-off into self-sustained growth. Economic Journal. 66: 25-48. 
Rostow, W.W. 1960. The stages of economic growth. Cambridge: Cambridge University Press.

Rostow, W.W. (ed.). 1963. The economics of take-off into sustained growth. London: Macmillan.

Rostow, W.W. 1984. Development: the political economy of the Marshallian long-period. In Pioneers in development, pp. 229-61, ed. by G.M. Meier and D. Seers. New York: Oxford University Press.

Samuelson, P.A. 1948a. Economics, 1st edition. New York: McGraw-Hill.

Samuelson, P.A. 1948b. International trade and equalisation of factor prices. 58: 163-84.

Samuelson, P.A. 1955. Economics, $3^{\text {rd }}$ edition. New York: McGraw-Hill.

Samuelson, P.A. 1958. An exact consumption-loan model with or without the social contrivance of money. Journal of Political Economy. 66: 467-82.

Samuelson, P.A. 1961. Economics, $5^{\text {th }}$ edition. New York: McGraw-Hill.

Samuelson, P.A. 1964. Economics, $6^{\text {th }}$ edition. New York: McGraw-Hill.

Samuelson, P.A. 1965a. A theory of induced innovations along Kennedy-Weizsäcker lines. Review of Economics and Statistics. 47: 343-56.

Samuelson, P.A. 1965b. A catenary turnpike theorem involving consumption and the golden rule. American Economic Review. 55: 486-96.

Samuelson, P.A. 1966. Rejoinder: agreements, disagreements, doubts and the case of induced Harrod-neutral technical change. Review of Economics and Statistics. 48: 444-48.

Samuelson, P.A. 1967. Economics, $7^{\text {th }}$ edition. New York: McGraw-Hill.

Samuelson, P.A. [1956] 1969. Public responsibility for growth and stability. In Phelps, E.S. (ed.). 1969. The goal of economic growth, $2^{\text {nd }}$ edition. New York: Norton,pp. 70-73.

Samuelson, P.A. 1973. Economics, $9^{\text {th }}$ edition. New York: McGraw-Hill.

Samuelson, P.A. 1976. Economics, $10^{\text {th }}$ edition. New York: McGraw-Hill.

Samuelson, P.A. 2001. Sparks and grit from the anvil of growth. In Frontiers of Development Economics, edited by G. Meier and J. Stiglitz. New York: Oxford University Press.

Sato, K. 1966. Discussion. American Economic Review. 56: 78-80.

Schumpeter, J.A. [1911]1934. The theory of economic development: An inquiry into profits, capital, credit, interest and the business cycle. Cambridge, MA: Harvard University Press.

Schumpeter, J.A. 1942. Capitalism, socialism and democracy. New York: Harper and Brothers.

Sen, A.K. 1970. Growth Economics: Selected Readings. London: Penguin.

Shell, K. 1966. Toward a theory of inventive activity and capital accumulation. American Economic Review. 56: 62-68.

Shell, K. (ed.). 1967a. Essays on the theory of optimal economic growth. Cambridge (Mass): MIT Press. 
Shell, K. 1967b. A model of inventive activity and capital accumulation. In Shell (ed.), pp. 6785.

Shell, K. 1973. Inventive activity, industrial organisation and economic growth. In Mirrlees and Stern (eds.) 1973, pp. 77-96.

Sheshinski, E. 1966. Essays on the theory of production and technical progress. PhD thesis. MIT.

Sheshinski, E. 1967a. Optimal accumulation with learning by doing. In Shell (ed.) 1967a, pp. 3152.

Sheshinski, E. 1967b. Tests of the "learning by doing” hypothesis. Review of Economics and Statistics. 49: 568-78.

Sheshinski, E. 1990. Comments: fixed costs in investment theory. In Diamond (ed.) 1990, pp. 41-49.

Solow, R.M. 1956. A contribution to the theory of economic growth. Quarterly Journal of Economics. 70: 65-94.

Solow, R.M. 1957. Technical change and the aggregate production function. Review of Economics and Statistics. 39: 748-62.

Solow, R.M. 1960. Investment and technical progress. In Mathematical methods in the social sciences 1959, pp. 89-104, ed. by K.J. Arrow and S. Karbin. Stanford: Stanford University Press.

Solow, R.M. 1962. Technical progress, capital formation, and economic growth. American Economic Review. 52: 76-86.

Solow, R.M. [1962]1964. Economic growth. In Economic Growth: An American Problem, pp. 101-115, ed. by P.M. Gutmann. Englewood Cliffs: Prentice-Hall. [Originally presented in a conference in May 1962.]

Solow, R.M. 1966. Lectures on growth theory. Typed manuscript. Solow Papers, Duke Archives.

Solow, R.M. 1967. Some recent developments in the theory of production. In The theory and empirical analysis of production, pp. 25-50, ed. by M. Brown. New York: NBER.

Solow, R.M. 1970. Growth theory - an exposition. New York: Oxford University Press.

Solow, R.M. 1973. Is the end of the world at hand? Challenge. 16: 39-50.

Solow, R.M. 1983. Modern capital theory. In Paul Samuelson and modern economic theory, pp. 169-87, ed. by E.C. Brown and R.M. Solow. New York: McGraw-Hill.

Solow, R.M. 1991. Growth theory. In Companion to contemporary economic thought, pp. 393415, ed. by D. Greenaway, M. Bleaney and I. Stewart. London: Routledge.

Solow, R.M. 1997. Learning from “learning by doing”: lessons for economic growth. Stanford (CA): Stanford University Press.

Solow, R.M. 2000. The Kennedy Council and the long run. In Economic events, ideas and policies: the 1960s and after, pp. 111-35, ed. by G.L. Perry and J. Tobin. Washington D.C.: Brookings Institution. 
Solow, R.M. 2010. Stories about economics and technology. European Journal of the History of Economic Thought. 17: 1113-26.

Swan, T.W. 1956. Economic growth and capital accumulation. Economic Record. 32: 334-61.

Stiglitz, J. 1966. Studies in the theory of economic growth and income distribution. PhD thesis. MIT.

Stiglitz, J. 1969. Discussion. American Economic Review. 59: 46-49.

Stiglitz, J. 1990. Comments: some retrospective views on growth theory. In Diamond (ed.) 1990, pp. 50-68.

Stiglitz, J. and H. Uzawa (eds.). 1969. Readings in the modern theory of economic growth. Cambridge (Mass.): MIT Press.

Tobin, J. 1964. Economic growth as an objective of government policy. American Economic Review. 54: 1-20.

Wan, H. Y., Jr. 1971. Economic growth. New York: Harcourt Brace Jovanovich.

Warsh, D. 2006. Knowledge and the Wealth of Nations. New York: Norton.

Weintraub, E.R. 1991. Stabilizing dynamics: Constructing economic knowledge. Cambridge: Cambridge University Press.

Wulwick, N.J. 1999. The Hamiltonian formalism and optimal growth theory. In Measurement, quantification and economic analysis: numeracy in economics, pp. 406-35, ed. by I. Rima. London: Routledge. 